\title{
Plant density and nitrogen fertilization in Swiss chard
}

\author{
Márcia de M Echer'; Tiago Zoz²; Charles Douglas Rossol'; ${ }^{1}$ Fábio Steiner²; Deise D Castagnara'; Maria \\ do C Lana ${ }^{1}$ \\ ${ }^{1}$ UNIOESTE, C. Postal 91, 85960-000 Marechal Cândido Rondon-PR; mmecher@bol.com.br; rossol.unioeste@gmail.com; \\ deisecastagnara@yahoo.com.br; mclana@unioeste.br; ${ }^{2}$ UNESP-FCA, Depto. Agricultura, C. Postal 237, 18610-370 Botucatu-SP; \\ tiagozoz@fca.unesp.br; fsteiner@fca.unesp.br
}

\begin{abstract}
An experiment was conducted to evaluate the effect of plant spacing and nitrogen fertilization on Swiss chard's yield, from September to November 2009. The experimental design was of randomized blocks in split plot with four replications. In the plots were allocated the two plant spacings $(0.30$ and $0.50 \mathrm{~m})$ and in the subplots the five doses of nitrogen $\left(0,40,80,120\right.$ and $\left.160 \mathrm{~kg} \mathrm{ha}^{-1}\right)$. The crop was harvested 90 days after transplanting. The plant spacing of $0.50 \mathrm{~m}$ provided increased production of total fresh weight of shoot (961.7 g plant $\left.^{-1}\right)$ and marketable (873.1 g plant $\left.^{-1}\right)$. However, the highest total yield $\left(77.8 \mathrm{t} \mathrm{ha}^{-1}\right)$ and marketable $\left(64.5 \mathrm{t} \mathrm{ha}^{-1}\right)$ was achieved with the smaller spacing between plants $(0.30 \mathrm{~m})$. The $\mathrm{N}$ rates applied in coverage until $160 \mathrm{~kg} \mathrm{ha}^{-1}$ increased in a linear form the total and marketable production of fresh mass of shoots, the total and marketable yield, the $\mathrm{N}$ content and the $\mathrm{N}$ accumulation in the shoots of Swiss chard plants on the evaluated plant spacings.
\end{abstract}

Keywords: Beta vulgaris var. cycla, nitrogen, yield.

\section{RESUMO}

\section{Densidade de plantio e adubação nitrogenada em acelga}

Avaliou-se o efeito do espaçamento entre plantas e da adubação nitrogenada na produtividade de acelga, de setembro a novembro de 2009. O delineamento experimental adotado foi de blocos ao acaso em parcelas subdivididas com quatro repetições. Nas parcelas foram alocados dois espaçamentos entre plantas $(0,30$ e $0,50 \mathrm{~m})$ e nas subparcelas cinco doses de nitrogênio em cobertura $(0 ; 40,80,120$ e $\left.160 \mathrm{~kg} \mathrm{ha}^{-1}\right)$. A colheita foi realizada 90 dias após o transplante das mudas. O espaçamento entre plantas de $0,50 \mathrm{~m}$ proporciona maior produção de massa fresca da parte aérea total $\left(961,7 \mathrm{~g} \mathrm{planta}^{-1}\right) \mathrm{e}$ comercial $\left(873,1 \mathrm{~g} \mathrm{planta}^{-1}\right)$ por planta. Porém, a maior produtividade total $\left(77,8 \mathrm{t} \mathrm{ha}^{-1}\right)$ e comercial $\left(64,5 \mathrm{t} \mathrm{ha}^{-1}\right)$ foi obtida com o menor espaçamento entre plantas $(0,30 \mathrm{~m})$. As doses de $\mathrm{N}$ aplicadas em cobertura até $160 \mathrm{~kg} \mathrm{ha}^{-1}$ incrementam de forma linear a produção de massa fresca da parte aérea total e comercial, a produtividade total e comercial, o teor de $\mathrm{N}$ e o $\mathrm{N}$ acumulado na parte aérea das plantas de acelga nos espaçamentos avaliados.

Palavras-chave: Beta vulgaris var. cycla, nitrogênio, produtividade.

(Recebido para publicação em 31 de agosto de 2011; aceito em 30 de agosto de 2012)

(Received on August 31, 2011; accepted on August 30, 2012)

$\mathrm{T}^{\mathrm{k}}$ he Swiss chard (Beta vulgaris var. cycla) is a leafy vegetable, biennial, of long cycle from Europe belonging to the Chenopodiaceae family. This vegetable is characterized by having large ovate leaves with armored edges, the color varies according to the cultivar from dark green to light green, and has creamy or white colored petiolates (Filgueira, 2008). It is a temperate climate plant, which grows best in warm weather, with temperatures ranging between 18 and $25^{\circ} \mathrm{C}$ (Costa et al., 2003). Currently, the Swiss chard cultivation has been gaining ground and economic importance among leafy vegetables. However, there is little technical information about their culture, mainly in concerning to mineral nutrition and planting density.

Planting density is one of the main factors influencing crop yield (López-
Bellido et al., 2005). The increase in the number of plants per area reduces the production of fresh weight per plant and increases yield to some extent. The Swiss chard is normally planted in the field with 0.45 to $0.6 \mathrm{~m}$ between rows and 0.25 to $0.30 \mathrm{~m}$ spacing between plants (Daeard, 2011). The adjustment of spacing is necessary for each cultivar, to prevent the leaf area, important in photoassimilates supply, to be affected in any way prejudicing the productivity (Castro et al., 1987).

In addition to planting density, fertilization also alters crop yields, being one of the farming practices with higher cost and economic return, resulting in higher yields, more uniform products and higher marketable value (Ricci et al., 1995). In leafy vegetables such as Swiss chard, nitrogen $(\mathrm{N})$ plays a fundamental role in vegetative growth and hence yield and product quality. This crop presents nutrient extraction efficiency, providing high short-term yield (Filgueira, 2008). However, it is possible that excessive $\mathrm{N}$ can accumulate in plants as nitrate $\left(\mathrm{NO}^{-3}\right)$ being detrimental to health.

Studies aiming to evaluate the distribution of plants and Swiss chard fertilization with $\mathrm{N}$ are scarce in Brazil. This study aimed to evaluate the effect of plant spacing and $\mathrm{N}$ fertilization on Swiss chard's yield.

\section{MATERIAL AND METHODS}

The experiment was conducted in the UNIOESTE University (243' S, $54^{\circ} 04^{\prime} \mathrm{W}$, altitude $420 \mathrm{~m}$ ) between September and November 2009. According to Köppen's classification, the climate is Cfa, mesothermal humid 
subtropical with hot summers, winters with infrequent frosts, no dry season, with $21.4^{\circ} \mathrm{C}$ average annual temperature and $1,500 \mathrm{~mm}$ precipitation.

The soil is classified as typical Oxisol, deep, well drained and with loamy texture (640 $\mathrm{g} \mathrm{kg}^{-1}$ clay) (Embrapa, 2006). The chemical analysis of the soil, performed at $0-20 \mathrm{~cm}$ prior to the experiment, showed the following results: $5.2 \mathrm{pH}$ in $\mathrm{CaCl}_{2}, 16 \mathrm{~g} \mathrm{dm}^{-3}$ organic matter, $85 \mathrm{t} \mathrm{dm}^{-3} \mathrm{P}$ (Mehlich-1), $48 \mathrm{mmol} \mathrm{dm}^{-3} \mathrm{H}+\mathrm{Al}, 3.1 \mathrm{mmol} \mathrm{dm}^{-3}$ $\mathrm{K}^{+}, 54 \mathrm{mmol} \mathrm{dm}^{-3} \mathrm{Ca}^{2+}, 14 \mathrm{mmol}_{\mathrm{c}} \mathrm{dm}^{-3}$ $\mathrm{T}^{2+}, 118 \mathrm{mmol}_{\mathrm{c}} \mathrm{dm}^{-3} \mathrm{CTC}$ and $60 \%$ saturation.

The experimental design was of randomized blocks in a split plot design with four replications. Two plant spacings were allocated in plots $(0.30$ and $0.50 \mathrm{~m}$ between rows) and five nitrogen doses in the subplots $(0,40$, 80,120 and $160 \mathrm{~kg} \mathrm{ha}^{-1}$ ). The subplot consisted of three rows spaced by 0.40 $\mathrm{m}$ and five plants per row, totaling 15 plants. Side dressing nitrogen doses were divided in three applications at 14, 21 and 28 days after transplanting. Urea Super $\mathrm{N}^{\circledR}(45 \% \mathrm{~N})$ was used as the nitrogen source. Seedlings of Swiss chard (Blonde cultivar) were grown in a greenhouse, in expanded polystyrene trays with 128 cells, supplied with marketable substrate Plantmax HA composed of expanded vermiculite and organic matter of vegetable origin. At 45 days after sowing, seedlings were transplanted to beds with $1.20 \mathrm{~m}$ wide and $0.20 \mathrm{~m}$ elevation. The basic fertilization at transplantation was performed by applying $40 \mathrm{~kg} \mathrm{ha}^{-1} \mathrm{~N}$, $180 \mathrm{~kg} \mathrm{ha}^{-1} \mathrm{P}_{2} \mathrm{O}_{5}$ and $100 \mathrm{~kg} \mathrm{ha}^{-1} \mathrm{~K}_{2} \mathrm{O}$. Fertilizers were distributed manually on the soil surface and incorporated until the $0-15 \mathrm{~cm}$ layer. Irrigation was performed by spraying twice a day: the first in the morning and second in the afternoon. Weed control was carried out with hand weeding.

The crop was harvested 90 days after seedlings transplantation. Three central plants of each subplot were cut close to the soil surface and taken to the laboratory. Plant height and fresh weight production in the total and marketable shoot were measured. The production of marketable fresh weight was obtained after removal of damaged leaves or those unfit for marketing. Total $\left(\mathrm{t} \mathrm{ha}^{-1}\right)$ and marketable yield $\left(\mathrm{t} \mathrm{ha}^{-1}\right)$ were extrapolated from production data per plant. Subsequently, plants were packed in paper bags and dried in forced-air oven at $55 \pm 3^{\circ} \mathrm{C}$ until constant weight. Afterwards, the material was ground and $\mathrm{N}$ content determined by Kjeldahl distillation (Tedesco et al., 1995).

Data were subjected to analysis of variance by $F$ test $(p \leq 0.05)$. Means related to spacing among plants were compared by the Tukey test $(\mathrm{p} \leq 0.05)$. Means referring to nitrogen levels were adjusted through regression equations, choosing the significant model with greater coefficient of determination $\left(\mathrm{R}^{2}\right)$. For data processing we used the statistical software version 4.0 SISVAR.

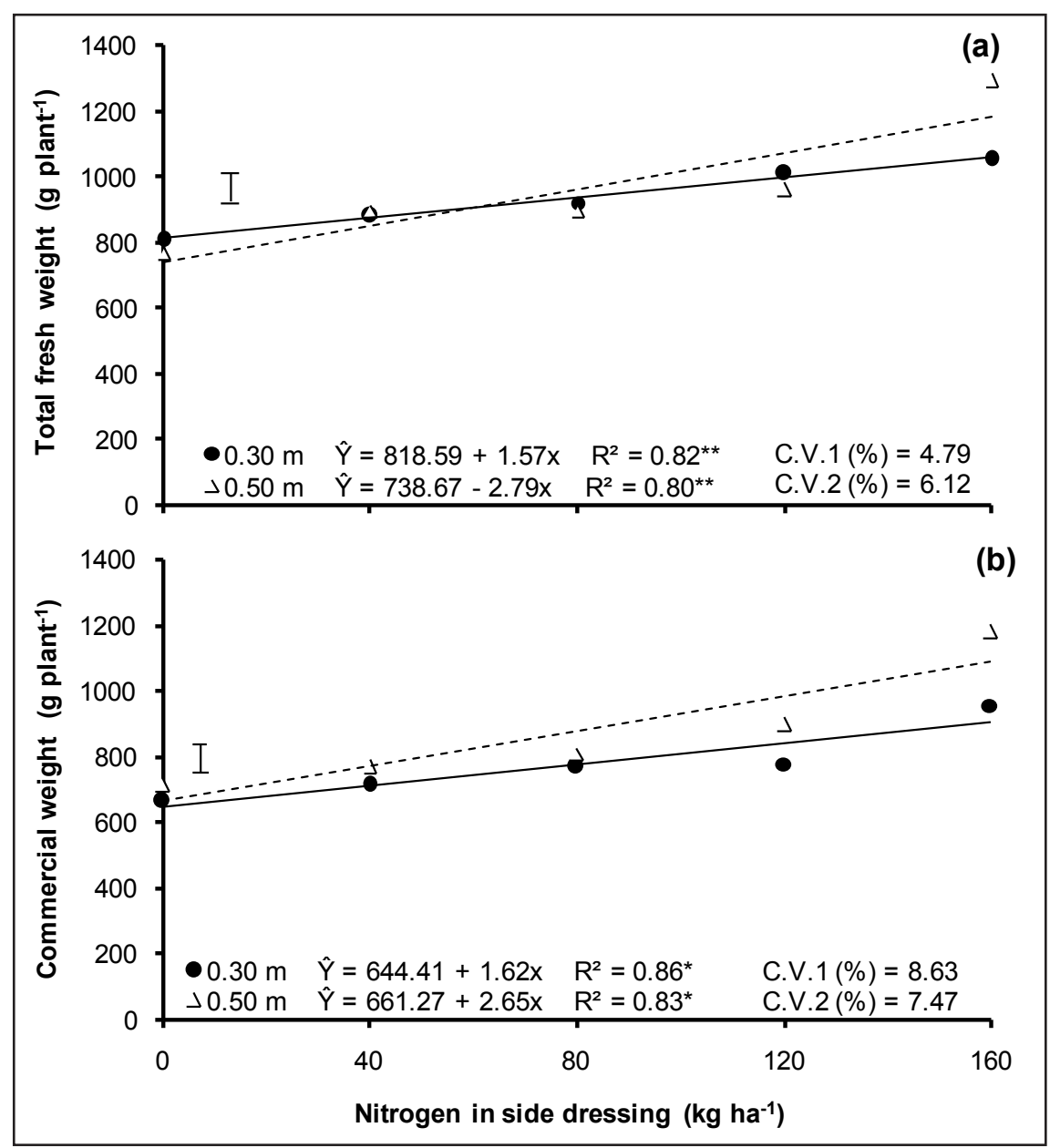

Figure 1. Total (a) and marketable weight (b) of Swiss chards grown at $0.30(\bullet)$ and $0.50 \mathrm{~m}$ $(\Delta)$ plant spacing with different doses of nitrogen application in side dressing (massa fresca total (a) e comercial (b) de plantas de acelga cultivadas no espaçamento entre plantas de 0,30 $(\bullet)$ e $0,50 \mathrm{~m}(\Delta)$ com a aplicação de nitrogênio em cobertura).** and * significant at 1 and $5 \%$ probability respectively; vertical bars represent the LSD $(\mathrm{p}<0.05))$. Marechal Cândido Rondon, UNIOESTE, 2009. 


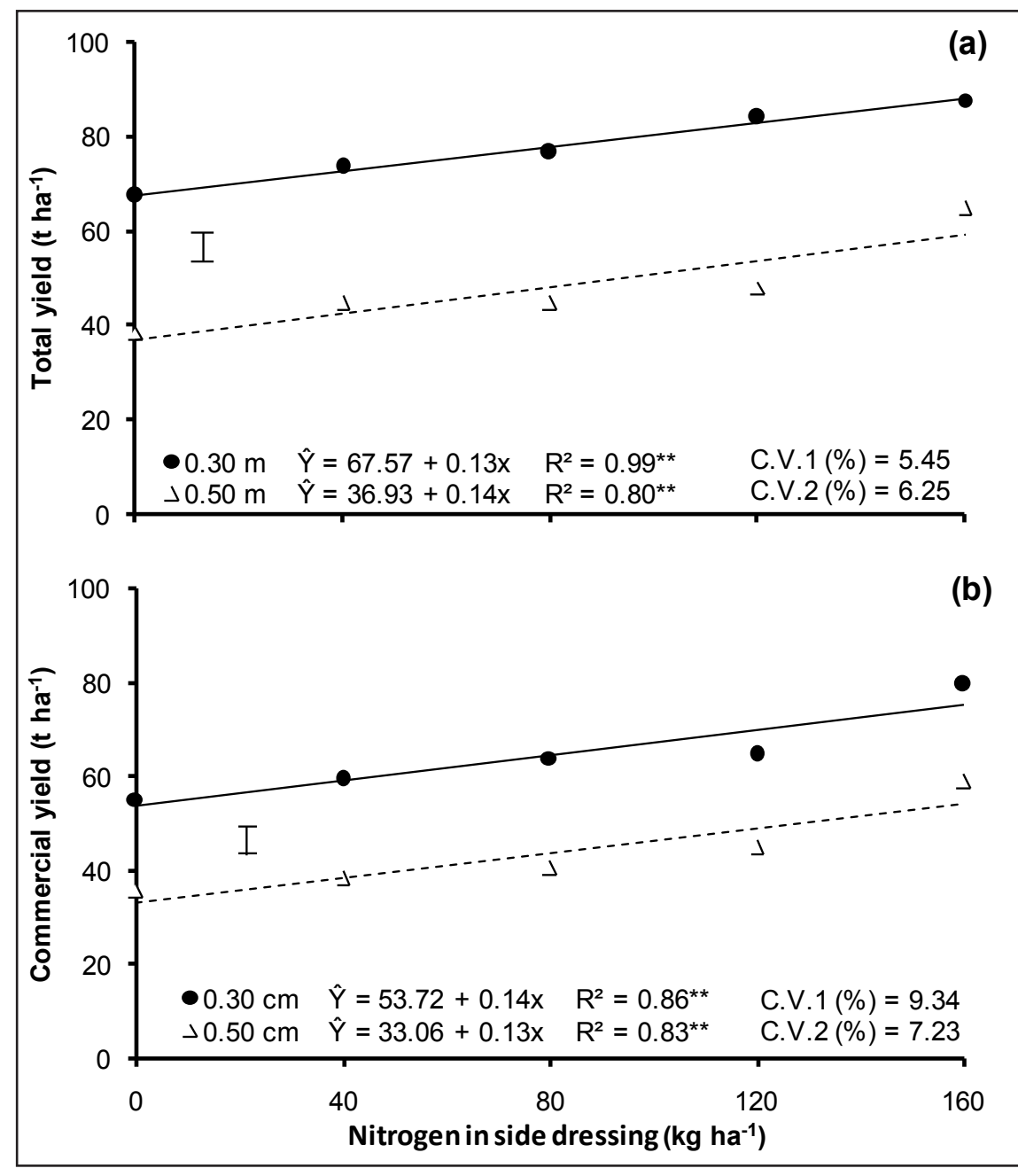

Figure 2. Total (a) and marketable yield (b) of Swiss chards grown at $0.30(\bullet)$ and $0.50 \mathrm{~m}$ $(\Delta)$ plant spacing with different doses of nitrogen application in side dressing (produtividade total (a) e comercial (b) de acelga cultivada no espaçamento entre plantas de $0,30(\bullet)$ e $0,50 \mathrm{~m}(\Delta)$ com a aplicação de nitrogênio em cobertura).** and * significant at 1 and $5 \%$ probability respectively; vertical bars represent the LSD $(\mathrm{p}<0.05))$. Marechal Cândido Rondon, UNIOESTE, 2009.

$0.50 \mathrm{~m}$ plant spacing was due to higher $\mathrm{N}$ availability in the soil that can be absorbed by the plant. There was lower intraspecific competition for light, water and nutrients in the greater plant spacing favoring the further growth and development of plants.

The lower production of marketable fresh weight obtained at $0.30 \mathrm{~m}$ plant spacing with 120 and $160 \mathrm{~kg} \mathrm{ha}^{-1}$ of $\mathrm{N}$ fertilization (Figure $1 \mathrm{~b}$ ) was due to increased disposal of leaves infected by diseases, making them unfit for the market. Less spacing between plants and consequently higher density, favored diseases proliferation, infecting the lower leaves of Swiss chard plants. According to Filgueira (2008), excess weight of shoots (Figure 1a) for each $40 \mathrm{~kg} \mathrm{ha}^{-1} \mathrm{~N}$ applied in side dressing at 0.30 and $0.50 \mathrm{~m}$ of plant spacing, respectively. For marketable fresh weight production (Figure 1b) occurred an increase of 64.8 and $106.0 \mathrm{~g}$ per 40 $\mathrm{kg} \mathrm{ha}^{-1} \mathrm{~N}$ applied in side dressing at 0.30 $\mathrm{m}$ and 0.50 plant spacing, respectively.

In cabbage, Aquino et al. (2005) observed increased head fresh weight production with $\mathrm{N}$ application up to 300 $\mathrm{kg} \mathrm{ha}^{-1}$. Pereira et al. (2003) showed linear response in the fresh weight production of lettuce to $\mathrm{N}$ application. Resende et al. (2005) found quadratic effect for the total and marketable fresh weight production of lettuce depending on the $\mathrm{N}$ application, with maximum production (763 $\mathrm{g} \mathrm{plant}^{-1}$ ) obtained by applying $147 \mathrm{~kg} \mathrm{ha}^{-1} \mathrm{~N}$. For total and marketable yield occurred the reverse of fresh weight production per plant and the plant spacing of $0.30 \mathrm{~m}$ promoted highest yield of Swiss chard compared to the spacing of $0.50 \mathrm{~m}$ at all $\mathrm{N}$ doses in side dressing (Figure 2a and 2b). The highest yield of Swiss chard obtained at the smallest spacing can be attributed to the greater number of plants per area. Similar results were observed by Aquino et al. (2005) evaluating cabbage development in three rows, who found highest yield of fresh weight of heads per area at smaller spacing. Silva (2005), evaluating cabbage cultivation at different spacing between plants and between rows, found that, by reducing the spacing, occurred an increased production per area.

Nitrogen application promoted linear increase in total (Figure 2a) and marketable yield (Figure 2b) in both row spacing studied. There was 5.2 and $5.6 \mathrm{tha}^{-1}$ increase of total yield (Figure 2a) and 5.6 and $5.2 \mathrm{t} \mathrm{ha}^{-1}$ for marketable yield (Figure 2a) of Swiss chard for each $40 \mathrm{~kg} \mathrm{ha}^{-1} \mathrm{~N}$ applied in side dressing, respectively, at 0.30 and 0.50 $\mathrm{m}$ plant spacing. Results are consistent with those obtained by Marques et al . (2010) who found increase in total and marketable production of sugar beet with manure application and attributed such production increase to the $\mathrm{N}$ present in manure. However, Aquino et al. (2006), applying $\mathrm{N}$ rates in sugar beet obtained quadratic adjustment in 


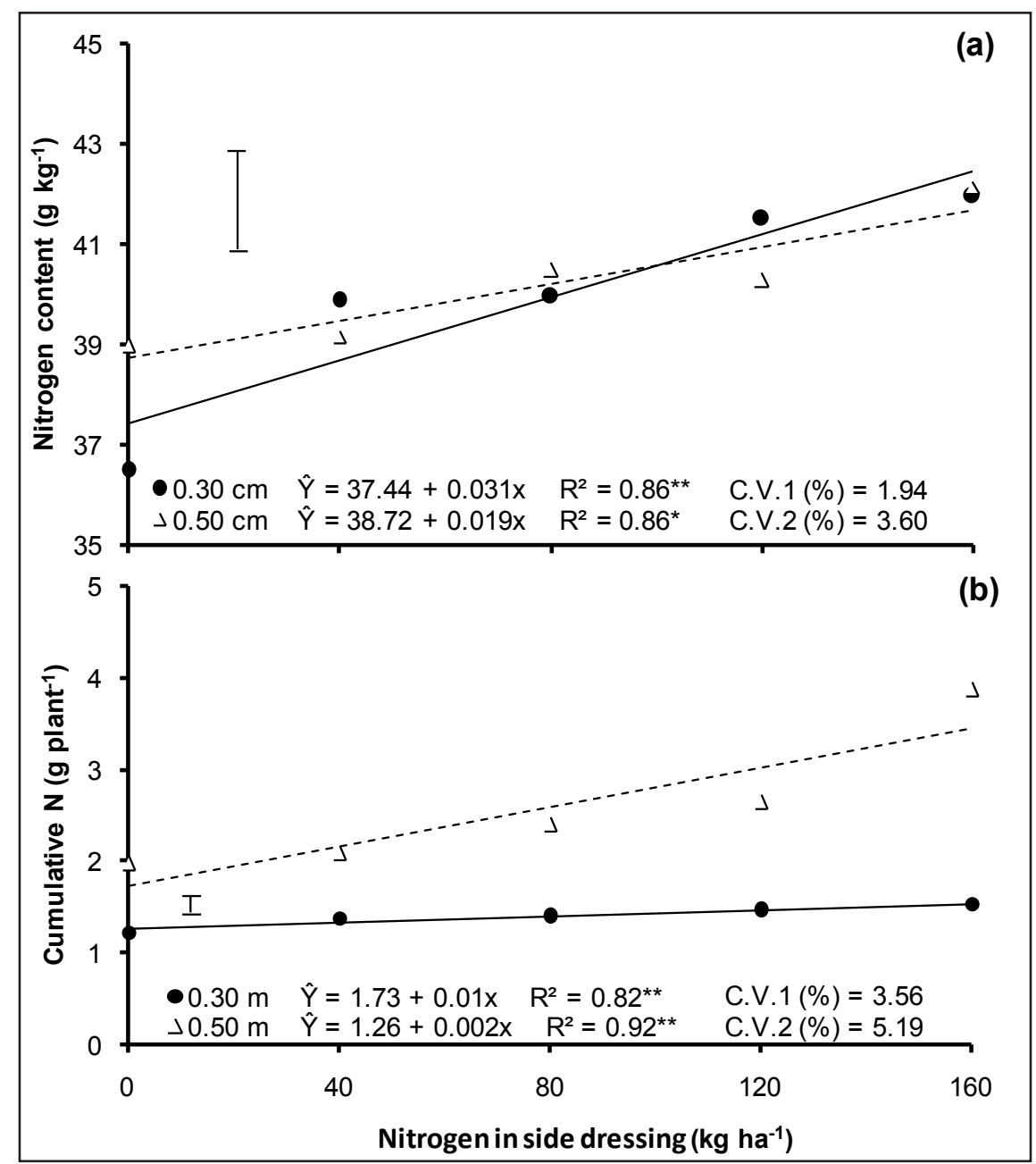

Figure 3. Nitrogen content (a) and cumulative $\mathrm{N}(\mathrm{b})$ in the shoots of Swiss chard grown at 0.30 $(\bullet)$ and $0.50 \mathrm{~m}(\Delta)$ plant spacing with different doses of nitrogen application in side dressing (teor de nitrogênio (a) e $\mathrm{N}$ acumulado (b) na parte aérea de plantas de acelga cultivadas no espaçamento entre plantas de $0,30(\bullet)$ e $0,50 \mathrm{~m}(\Delta)$ com a aplicação de nitrogênio em cobertura). ${ }^{* *}$ and $*$ significant at 1 and $5 \%$ probability, respectively. Vertical bar represents the LSD $(\mathrm{p}<0.05))$. Marechal Cândido Rondon, UNIOESTE, 2009.

the fresh weight production of leaves and roots. Assessing the effect of spacing and $\mathrm{N}$ doses on cabbage heads yield, Aquino et al. (2005) obtained a quadratic adjustment at 0.40 and $0.60 \mathrm{~m}$ row spacing and linear increase at 0.80 $\mathrm{m}$ spacing. Also working on cabbage under $\mathrm{N}$ fertilization, Moreira et al. (2011) obtained quadratic adjustment for fresh weight production with maximum production at $277.8 \mathrm{~kg} \mathrm{ha}^{-1} \mathrm{~N}$.

Total $\mathrm{N}$ content of Swiss chard shoots was not affected by spacing between plants. However, there was significant effect of $\mathrm{N}$ application in side dressing (Figure 3a). For each 40 $\mathrm{kg} \mathrm{ha}^{-1} \mathrm{~N}$ in side dressing there was 1.24 and $0.76 \mathrm{~g} \mathrm{~kg}^{-1} \mathrm{~N}$ increase at 0.30 and $0.50 \mathrm{~m}$ spacing, respectively. These results corroborate those obtained by Aquino et al. (2005) who, evaluating productivity, quality and nutritional status of table beet under $\mathrm{N}$ application, found linear increase in sugar beet's leaf $\mathrm{N}$ content according to $\mathrm{N}$ dose increase. Similarly, Trani et al. (2005) showed linear increase in leaf $\mathrm{N}$ content of sugar beet with ammonium sulfate application in side dressing.

For $\mathrm{N}$ amount accumulated in shoots, there were 0.08 and $0.40 \mathrm{~g}$ plant $^{-1}$ increment for each $40 \mathrm{~kg} \mathrm{~N} \mathrm{ha}^{-1}$ applied at 0.30 and $0.50 \mathrm{~m}$ spacing, respectively (Figure $3 b$ ). The highest $\mathrm{N}$ accumulation in shoots was obtained at $0.50 \mathrm{~m}$ plant spacing (Figure $3 \mathrm{~b}$ ). This result is probably because plants have higher production of fresh weight in shoots when grown at this plant spacing and hence higher dry weight, since there was no difference among plant spacing for total-N content in the shoot.

There was no influence of plant spacing and nitrogen application in side dressing on plant height with $67 \mathrm{~cm}$ average height.

The $0.50 \mathrm{~m}$ plant spacing promoted highest fresh weight production of total and marketable shoot per plant. However, the highest total and marketable yield is achieved with less spacing between plants $(0.30 \mathrm{~m})$. Doses of up to $160 \mathrm{~kg} \mathrm{~N} \mathrm{ha}^{-1}$ applied in side dressing promoted increased production of fresh weight in total and marketable shoots, total and marketable yield, $\mathrm{N}$ content and $\mathrm{N}$ accumulated in Swiss chard plants.

\section{REFERENCES}

AQUINO LA; PUIATTI M; PEREIRA PRG; PEREIRA FHF; CASTRO MRS; LADEIRA IR. 2005. Características produtivas do repolho em função de espaçamentos e doses de nitrogênio. Horticultura Brasileira 23: 266-270.

AQUINO LA; PUIATTI M; PEREIRA PRG; PEREIRA FHF; LADEIRA IR; CASTRO MRS. 2006. Produtividade, qualidade e estado nutricional da beterraba de mesa em função de doses de nitrogênio. Horticultura Brasileira 24: 199-203.

CASTRO PRC; FERREIRA SO; YAMADA T. 1987. Ecofisiologia da produção agrícola. Piracicaba: Associação Brasileira para Pesquisa da Potassa e do Fosfato. 249p.

COSTA SM; MONTENEGRO MA; ARREGUI T; PINTO MIS; NAZARENO MA; MISHIMA BL. 2003. Caracterización de acelga fresca de Santiago del Estero (Argentina). Comparación del contenido de nutrientes en hoja y tallo. Evaluación de los carotenoides presentes. Ciência e Tecnologia de Alimentos 23: 33-37.

DAEARD - Departament of Agriculture, environmental affairs \& rural developments. 2011, 24 de janeiro. Swiss chard. Disponível em: http://agriculture.kzntl.gov.za/downloads/ files/ Horticulture/swiss\%20chard.pdf/

EMBRAPA, Centro Nacional de Pesquisa em Solos. 2006. Sistema brasileiro de classificação de solos. Rio de Janeiro: Embrapa-Solos. 306p.

FILGUEIRA FAR. 2008. Novo manual de olericultura: agrotecnologia moderna na produção e comercialização de hortaliças. Viçosa: UFV. 421p.

LÓPEZ-BELLIDO FJ; LÓPEZ-BELLIDO L; LÓPEZ-BELLIDO RJ. 2005. Competition, growth and yield of faba bean (Vicia faba L.). European Journal of Agronomy 23: 359-378.

MARQUES LF; MEDEIROS DC; COUTINHO OL; MARQUES LF; MEDEIROS CB; VALE 
LS. 2010. Produção e qualidade da beterraba em função da adubação com esterco bovino. Revista Brasileira de Agroecologia 5: 24-31.

MOREIRA MA; VIDIGAL SM; SEDIYAMA MAN; SANTOS MR. 2011. Crescimento e produção de repolho em função de doses de nitrogênio. Horticultura Brasileira 29: 117-121.

PEREIRA OCN; BERTONHAA; FREITAS PSL; GONÇALVES ACA; REZENDE R; SIVA FF. 2003. Produção de alface em função de água e de nitrogênio. Acta Scientiarum. Agronomy
25: 381-386.

RESENDE GM; ALVARENGA MAR; YURI JE; MOTA, JH; SOUZA, RJ; RODRIGUES JÚNIOR JC. 2005. Produtividade e qualidade pós-colheita da alface americana em função de doses de nitrogênio e molibdênio. Horticultura Brasileira 23: 976-981.

RICCI MSF; CASALI VWD; CARDOSO AA; RUIZ HA. 1995. Teores de nutrientes em duas cultivares de alface adubadas com composto orgânico. Pesquisa Agropecuária Brasileira 30: 1035-1039.
SILVA GS. 2009. Crescimento e produtividade de repolho roxo em função de espaçamentos entre linhas e entre plantas. Jaboticabal: UNESP. 46p (Dissertação mestrado).

TEDESCO MJ; GIANELLO C; BISSANI CA; BOHNEN H; VOLKWEISS SJ. 1995. Análises de solo, plantas e outros materiais. Porto Alegre: UFRGS. 188p.

TRANI PE; CANTARELLA H; TIVELLI SW. 2005. Produtividade de beterraba em função de doses de sulfato de amônio em cobertura. Horticultura Brasileira 23: 726-730. 